\title{
铁酸盐提高 $\mathrm{g}-\mathrm{C}_{3} \mathrm{~N}_{4}$ 光催化产氢性能: 以铁酸镍和 铁酸钴为例
}

\author{
陈杰，赵大明，习志丹，汪淼，沈少华*
}

西安交通大学动力工程多相流国家重点实验室, 国际可再生能源研究中心, 西安 710049

* 联系人, E-mail: shshen_xjtu@xjtu.edu.cn

国家自然科学基金(51323011, 51236007)、新世纪优秀人才计划(NCET-13-0455)、陕西省自然科学基金(2014KW07-02)、江苏省自然科学基 金(BK20141212)、苏州纳米研究计划(ZXG201442, ZXG2013003)、全国优秀博士论文专项(201335)和中央高校基本科研业务费专项资助

高效低成本大规模太阳能光催化 分解水制氢是人类解决能源与环境问题 最有前景的途径. 其关键是寻找能够低 成本大规模制备、具有合适能带结构的 高活性光催化剂材料与高效产氢产氧助 催化剂, 以构建高效的光催化反应体系.

非金属聚合物半导体石墨型氮化 碳 $\left(\mathrm{g}-\mathrm{C}_{3} \mathrm{~N}_{4}\right)$ 具有很好的光化学稳定性、 合适的带隙和带边位置, 同时, $\mathrm{g}-\mathrm{C}_{3} \mathrm{~N}_{4}$ 制备方法简便、环境友好无重金属污 染, 前驱体来源丰富便宜, 满足低成 本大规模实际应用的先决条件. 然而, $\mathrm{g}-\mathrm{C}_{3} \mathrm{~N}_{4}$ 内部光生载流子极易复合, 导 致其光催化产氢效率一直处于较低水 平, 限制了其实际应用. 另一方面, 由
于 $g-\mathrm{C}_{3} \mathrm{~N}_{4}$ 中碳与氮形成大 $\pi$ 键, 产氢和 产氧反应位点无法在空间上有效分离. 目前的报道中, 只有负载铂、硫化钿等 产氢助催化剂时, $\mathrm{g}-\mathrm{C}_{3} \mathrm{~N}_{4}$ 才能表现出较 好的光催化制氢活性, 但没有同时提 高氧化催化半反应能力.

本课题组从光催化制氢的两个基 本过程, 即光生载流子分离和表面催化 反应人手, 在 $\mathrm{g}-\mathrm{C}_{3} \mathrm{~N}_{4}$ 上负载既能够与 $\mathrm{g}-\mathrm{C}_{3} \mathrm{~N}_{4}$ 形成II型异质结, 又具有良好的 表面催化反应能力的铁酸钴或铁酸镍, 以期同时提高载流子分离和表面催化 反应的效率, 从而极大地促进催化剂的 制氢效率(图1). 研究显示, 铁酸钴或铁 酸镍不仅能够有效地促进 $\mathrm{g}-\mathrm{C}_{3} \mathrm{~N}_{4}$ 中的
光生载流子分离, 而且能够高效催化表 面氧化半反应; 与此同时, 负载铂作为 产氢助催化剂, 促进表面催化还原产氢 半反应. 在光催化反应中, $\mathrm{g}-\mathrm{C}_{3} \mathrm{~N}_{4}$ 中的 光生电子和空穴分别流向铂和铁酸钴 或铁酸镍, 电子在铂上还原反应产生氢 气, 而空穴在铁酸钴或铁酸镍上与牺牲 剂反应快速消耗. 进一步研究发现, 铁 酸钴对 $\mathrm{g}-\mathrm{C}_{3} \mathrm{~N}_{4}$ 的载流子分离效果及其 氧化半反应催化能力都优于铁酸镍; 通过铁酸钴和铂的共负载, $\mathrm{g}-\mathrm{C}_{3} \mathrm{~N}_{4}$ 光催 化剂的制氢量子效率在 $420 \mathrm{~nm}$ 处达到 $3.35 \%$, 在可见光区 $(\lambda>420 \mathrm{~nm})$ 的光催 化制氢效率是未负载铁酸盐的 $\mathrm{g}-\mathrm{C}_{3} \mathrm{~N}_{4}$ 的3.5倍.
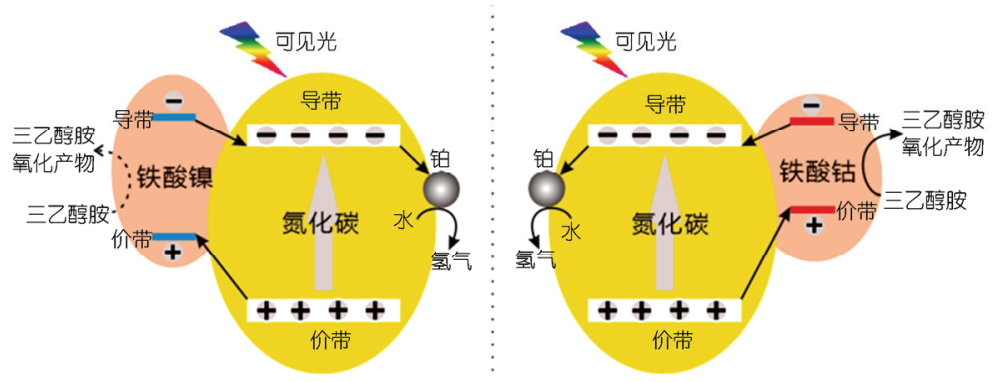

图 1 (网络版彩色)铁酸钴或铁酸镍负载氮化碳产氢反应机理示意图. 在II型能带结构的驱动下, $\mathrm{g}-\mathrm{C}_{3} \mathrm{~N}_{4}$ 空穴有更大的向铁酸钴转移驱动力, 而 且铁酸钴能更好地催化氧化三乙醇胺

全文见: Chen J, Zhao D M, Diao Z D, et al. Ferrites boosting photocatalytic hydrogen evolution over graphitic carbon nitride: a case study of $\left(\mathrm{Co}, \mathrm{Ni}^{2} \mathrm{Fe}_{2} \mathrm{O}_{4}\right.$ modification. Sci Bull, 2016, 61: 292-301 